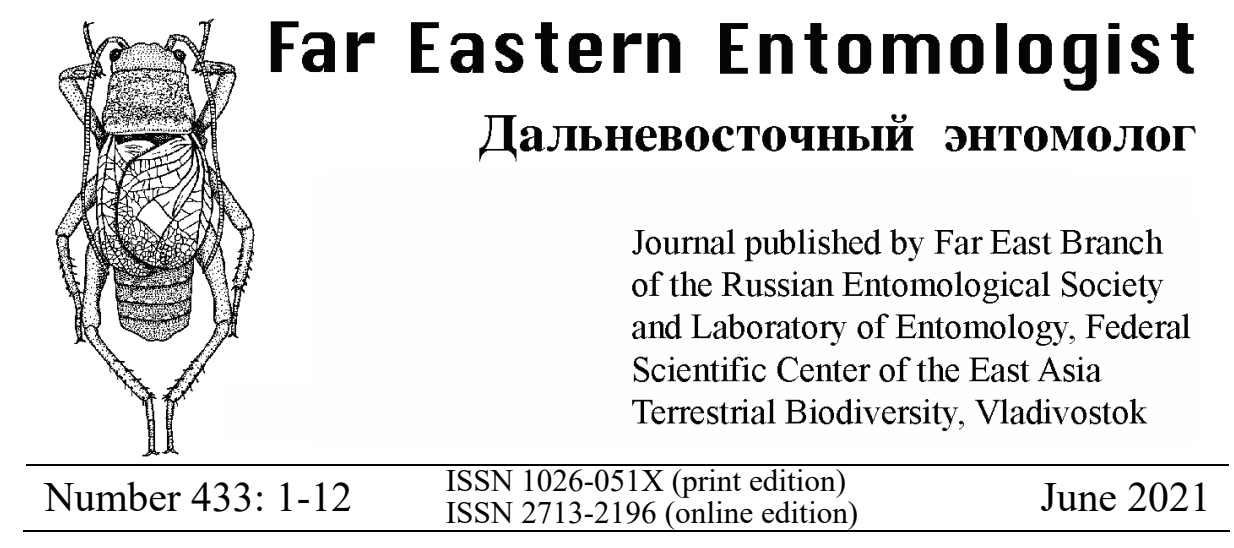

https://doi.org/10.25221/fee.433.1

http://zoobank.org/References/7361DC0A-136D-469A-B8A7-E46EC282DDEA

\title{
NEW SPECIES AND NEW RECORDS OF DERMESTIDAE (COLEOPTERA: BOSTRICHOIDEA) FROM MADAGASCAR
}

\section{J. Háva ${ }^{1)}$, K. Matsumoto ${ }^{2)}$}

1) Forestry and Game Management Research Institute, Strnady 136, CZ-156 00 Praha 5 - Zbraslav, Czech Republic.E-mail: jh.dermestidae@volny.cz

2) Department of Life Sciences, Natural History Museum, London, SW7 5BD, United Kingdom. E-mail: k.matsumoto@nhm.ac.uk

Summary. The new species Trogoderma tryznai sp. n., Trogoderma zhantievi sp. n. and Trogoderma sharpi sp. n. (Coleoptera: Dermestidae) from Madagascar are described, illustrated and compared with similar species. The new species differ from congeners by the structure of the antennae, male genitalia and colour of the elytral spots. Additional faunistic records of Madagascan Dermestidae and a key to species of Trogoderma are given.

Key words: skin beetles, Coleoptera, Dermestidae, taxonomy, new species, key, fauna, new records, Madagascar.

Дж. Хава, К. Матсумото. Новые виды и новые указания жуков-кожеедов (Coleoptera: Bostrichoidea, Dermestidae) с Мадагаскара // Дальневосточный энтомолог. 2021. N 433. C. 1-12.

Резюме. С Мадагаскара описаны и иллюстрированы новые для науки виды: Trogoderma tryznai sp. n., Trogoderma zhantievi $\mathbf{s p .}$. и и Trogoderma sharpi $\mathbf{s p .} \mathbf{n}$. (Coleoptera: Dermestidae). Новые виды отличаются от других представителей рода формой усиков, гениталиями самца и цветом пятен на надкрыльях. Для жуков-кожеедов Мадагаскара приводятся новые фаунистические данные и составлена определительная таблица мадагаскарских видов рода Trogoderma. 


\section{INTRODUCTION}

The family Dermestidae (Coleoptera: Bostrichoidea) includes 1715 valid species and subspecies worldwide (Háva, 2018, 2020). The dermestid genus Trogoderma Dejean, 1821, belonging to the subfamily Megatominae, includes 163 species worldwide and 13 species are known from Madagascar (Háva, 2009, 2013, 2014, 2015, 2018, 2020; Háva \& Herrmann, 2008; Háva \& Baňař, 2017). Three new species are described here, and new faunistic records of Phradonoma albonotatum (Pic, 1927); Trogoderma caneparii Háva, 2016; Trogoderma impressiceps (Pic, 1915) and Trinoparvus laboriosus Háva, 2004 are also included.

\section{MATERIAL AND METHODS}

The specimens used in this study are housed in the collection of the Natural History Museum, London (BMNH). The specimens were examined by relaxing in warm water, dissecting the abdomen and its inner contents. Genitalia are placed in a drop of dimethyl hydantoin formaldehyde (DMHF) resin and mounted on a card pinned under the specimen. Habitus photographs were taken with a Canon DSLR camera, Laowa $25 \mathrm{~mm}$ macro lens. All photographs were processed through focus stacking software, Helicon Focus and were later edited using GIMP. The beginning and end of label text are indicated using double quotes ("'); a double slash (//) separates the data on different labels.

The following acronyms of morphological characters were used: AS - antennal segment(s) (preceded by number increasing from antennal insertion to the tip of the last antennomere), BL - body length (pronotum length and elytral length), EL elytral length (elytral suture from the scutellum to the apex of elytra), EW maximum elytral width, $\mathrm{PL}$ - pronotal length, $\mathrm{PW}$ - maximum pronotal width.

\section{TAXONOMY}

\section{Trogoderma tryznai Háva et Matsumoto, sp. $n$.}

http://zoobank.org/NomenclaturalActs/FC718286-11B9-4393-A0D6-2B6AE1D91A8F

Figs 1-6

TYPE MATERIAL. Holotype - male, deposited at BMNH: "MADAGASCAR CE AMBAVANIASY vill. 3km N 9.-11.xi.2010, 752m, M.Trýzna \& P. Baňař lgt. // BMNH $\{$ E $\}$ 2015-39 // NHMUK014381544". Additional label on red paper added "Trogoderma tryznai sp. nov. Háva \& Matsumoto det. 2020 HOLOTYPE ${ }^{\text {X". }}$

DESCRIPTION. Male. Body: Oval and elongate, dorsum convex. BL: $2.8 \mathrm{~mm}$, EL: $2.2 \mathrm{~mm}$, EW: $1.7 \mathrm{~mm}$, PL: $0.7 \mathrm{~mm}$, PW: $1.5 \mathrm{~mm}$. Colour: Dorsal and ventral sides black; lateral margin of the pronotum brown; tibia light brown, tarsal claws light brown; 2nd to 9th AS light brown, 1st and 10th AS dark brown.

Body (Fig. 1). Head coarsely punctate with long light brown setation. Palpi entirely yellowish-brown; setation on mentum denser. Eye very large, with brown microsetae. Ocellus on front present (Fig. 4). Antennae with mixture of white and black setae, with ten antennomeres and 11th AS missing, quadrilateral with apical 


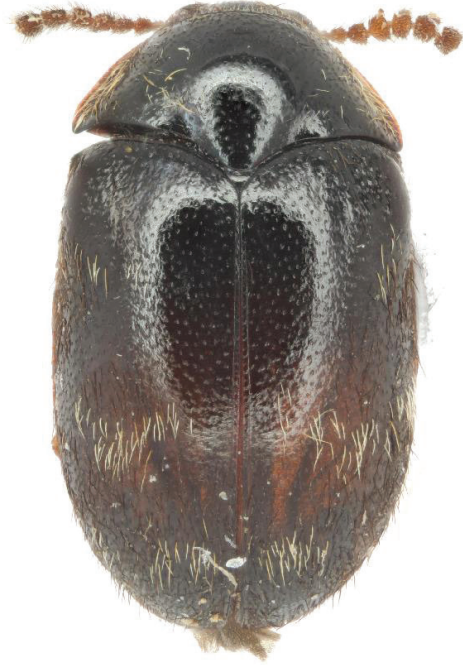

1

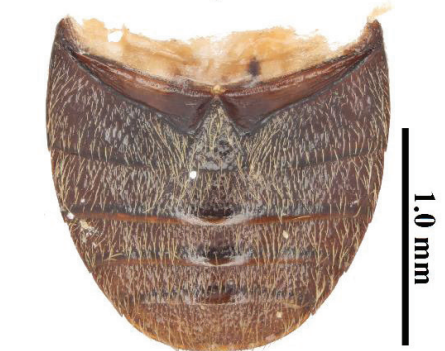

3

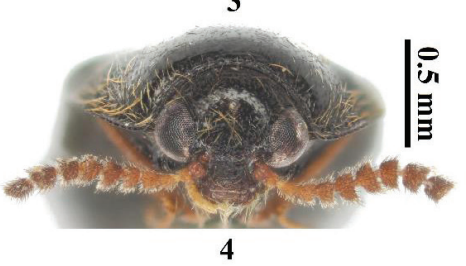

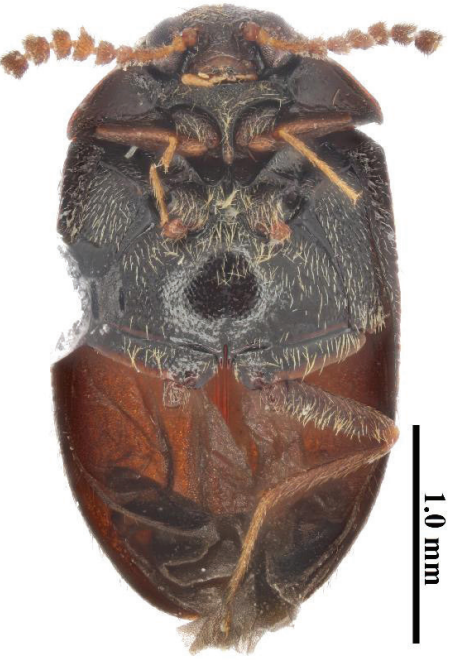

2

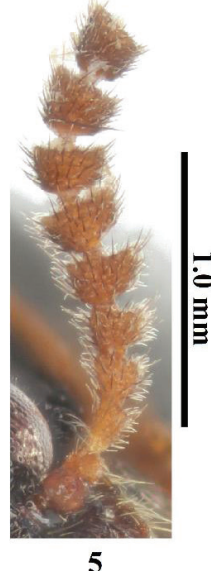

5

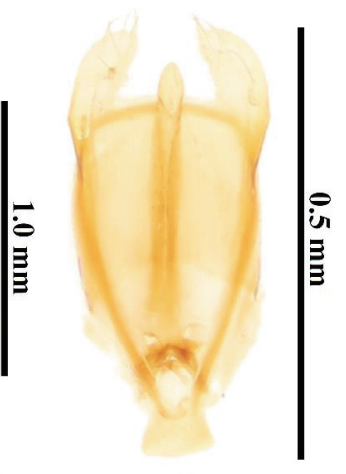

6

Figs 1-6. Trogoderma tryznai sp. n., holotype. 1 - dorsal habitus; 2 - ventral habitus; 3 abdomen; 4 - head frontal; 5-left antennae; 6 - genitalia ventral.

end longest, width increased from 1st to 6th AS and decreases towards the apical end (Fig. 5). Antennal fossa circular. Pronotum slightly more sparsely punctate compared to head, relatively consistent density of punctures, with relatively long yellowish-brown setation, and slightly shorter black station, most of the setae in the middle of pronotum may be eroded. Scutellum triangular, anterior end convex, without setation. Elytra coarsely punctate; surface reddish brown to black with three white bands of setation with black covering the rest of the surface, most of the setae 
in the middle of pronotum may be eroded (Fig. 1). Elytral epipleuron entirely black with white setation. Legs with light brown setation. Mesosternum finely punctate, covered with long light brown, recumbent setation (Fig. 2). Abdominal visible ventrites finely punctate, with long, recumbent, light brown setation (Fig. 4).

Genitalia (Fig. 6). Parameres: longer than median lobe, width very narrow from base to anterior $1 / 4$, increasing in width and gently curved towards middle from anterior 1/4 to apical end, apex rounded. Median lobe: constant width throughout, apical end slightly rounded. Phallobase: nearly symmetrical, oval.

Female. Unknown.

DISTRIBUTION. Madagascar.

DIFFERENTIAL DIAGNOSIS. The new species differs by its characteristic elytral colour; from other species known from Madagascar it differs by the characters given in the key below.

ETYMOLOGY. The epithet is a patronym honouring Miloš Trýzna (Czech Republic) who collected this species.

Trogoderma zhantievi Háva et Matsumoto, sp. n.

http://zoobank.org/NomenclaturalActs/8A8181AD-8F82-4737-A9F4-609BE7CECB8B

Figs $7-12$

TYPE MATERIAL. Holotype - male, deposited at BMNH: "MADAGASCAR 2011 AMBOHITANTELY Sp. Res 19.iv.; 1530 m, camp surr,; local collector leg. // BMNH $\{$ E $2015-39$ // NHMUK014381545". Additional label on red paper added "Trogoderma zhantievi sp. nov. Háva \& Matsumoto det. 2020 HOLOTYPE ${ }^{\text {X”. }}$

DESCRIPTION. Male. Body: Body: Oval, dorsum convex. BL: $1.8 \mathrm{~mm}$, EL: $1.3 \mathrm{~mm}$, EW: $1.2 \mathrm{~mm}$, PL: $0.5 \mathrm{~mm}$, PW: $1.0 \mathrm{~mm}$. Colour: Dorsal and ventral sides black; three bands of brown marking on the elytra; tibia brown, tarsal claws light brown; 2nd to 4th AS light brown, 1st and 5th to 11th AS dark brown.

Body (Fig. 7). Head densely punctate with short dark brown setation. Palpi entirely brown; setation on mentum denser. Eye very large, with brown microsetae. Ocellus on front present (Fig. 10). Antennae with brown setae, with eleven antennomeres, 1st and 2nd AS round and wider than 3rd to 7th AS, width gradually increased from 3rd to 10th AS, length increases from 8th to 11th AS, 11th AS longest and semicircular (Fig. 11). Antennal fossa circular. Pronotum coarsely punctate alike head with mixture of short black, light brown and white setation. Scutellum triangular, anterior end convex, without setation. Elytra coarsely punctate; surface with mixture of short black and light brown setation, and white setae occurs on the brown elytral band and near the apical end (Fig. 7). Elytral epipleuron entirely black with yellow setation. Legs with light brown setation. Mesosternum finely punctate, covered with short light brown, recumbent setation (Fig. 8). Abdominal visible ventrites finely punctate, with short, recumbent, mixture of light yellow and brown setation (Fig. 9).

Genitalia (Fig. 12). Parameres: longer than median lobe, width relatively constant from base to anterior $1 / 3$, increasing in width between anterior $1 / 3$ to apical end, apex slightly flattened. Median lobe: widest at base, constant width at middle towards apex, apical end slightly rounded. Phallobase: nearly symmetrical, trapezoid. 


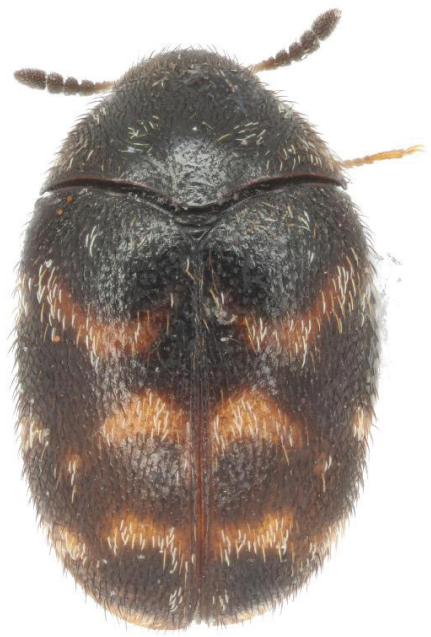

7

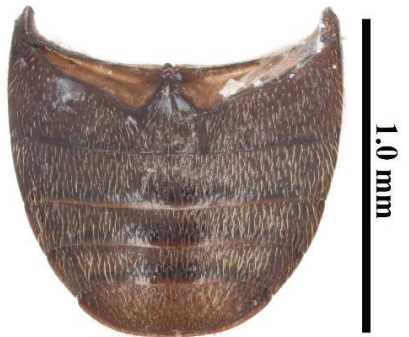

9

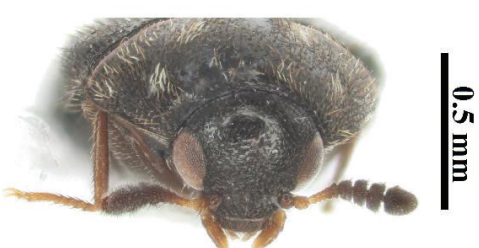

10

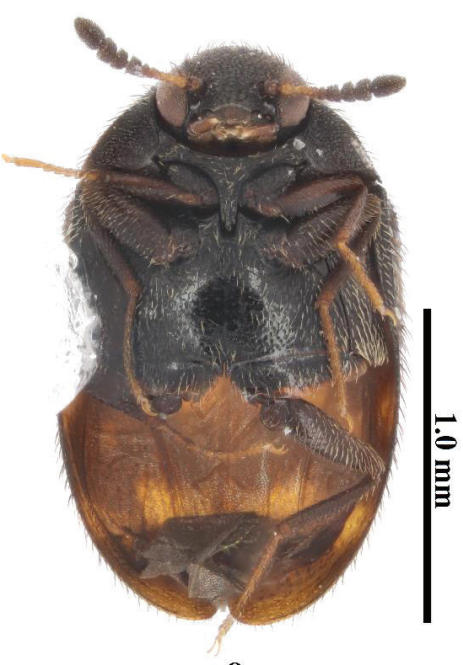

8

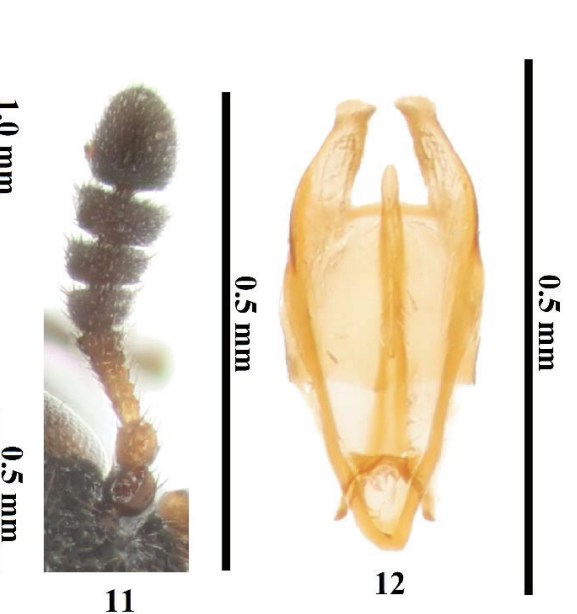

Figs. 7-12. Trogoderma zhantievi sp. n., holotype. 7 - dorsal habitus; 8 - ventral habitus; 9 - abdomen; 10 - head frontal; 11 - left antennae; 12 - genitalia ventral.

\section{Female. Unknown.}

DISTRIBUTION. Madagascar.

DIFFERENTIAL DIAGNOSIS. The new species similar to T. sahondrae Háva et Baňař, 2017 (Figs 22-24) but differs by its characteristic elytral colour; from other species known from Madagascar it differs by the characters given in the key below.

ETYMOLOGY. The epithet is a patronym honouring the Dermestidae specialist Rustem D. Zhantiev (Russia). 


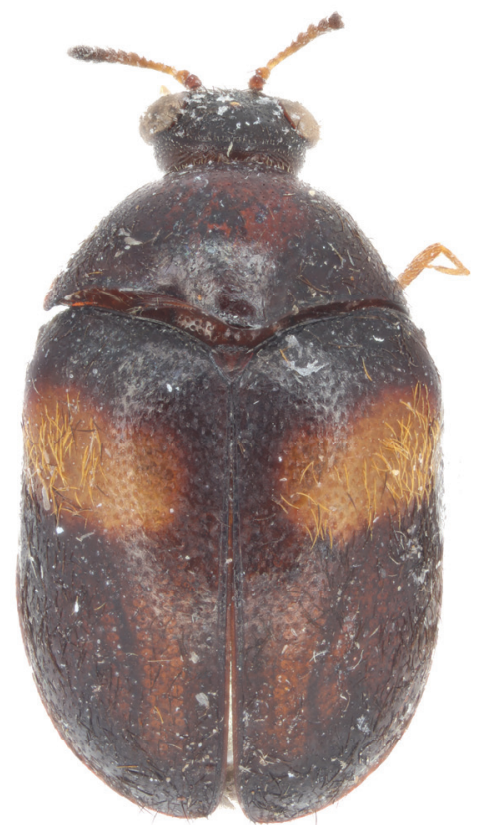

13

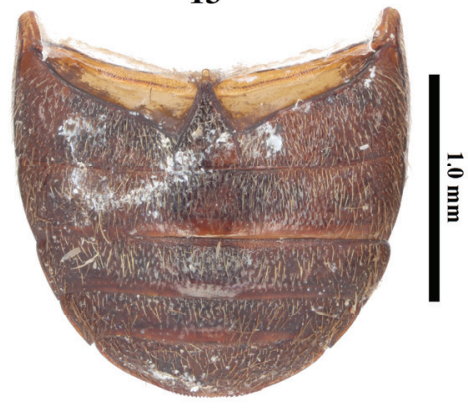

15

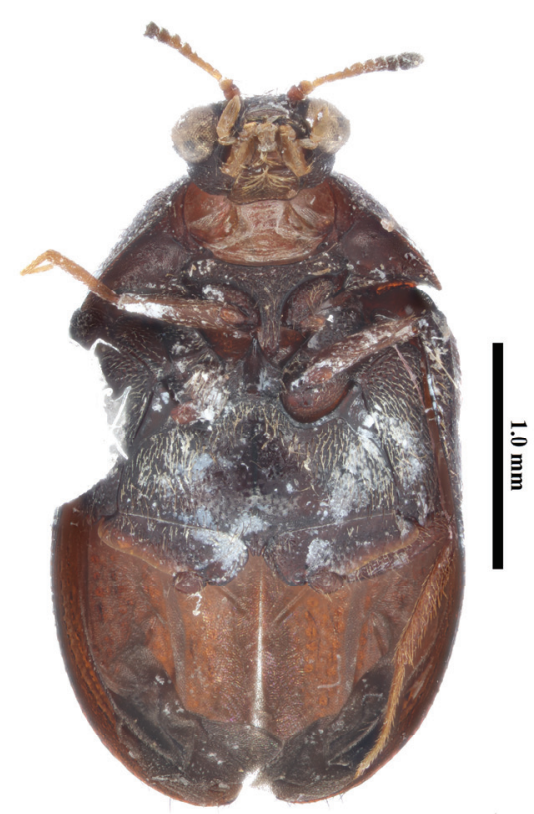

14

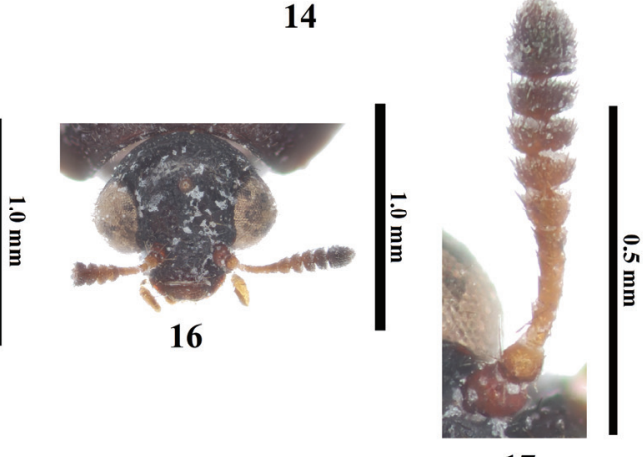

17

Figs. 13-17. Trogoderma sharpi $\mathbf{s p .}$ n., holotype. 13 - dorsal habitus; 14 - ventral habitus; 15 -abdomen; 16 - head frontal; 17 - left antennae.

\section{Trogoderma sharpi Háva et Matsumoto, sp. n.}

http://zoobank.org/NomenclaturalActs/A074A535-FB43-48D0-BDB3-25CBFD4DE206 Figs 13-17

TYPE MATERIAL. Holotype - female, deposited at BMNH: "MADAGASCAR, 2007, Ranomafana Nat. Park near Ranomafana vill., M. Trýzna leg., 26.-31.i., BMNH $\{$ E $\} 2010-29$ // NHMUK014381546". Additional label on red paper added "Trogoderma sharpi sp. nov. Háva \& Matsumoto det. 2020 HOLOTYPE @”. 
DESCRIPTION. Female. Body: Oval, dorsum convex. BL: $3.0 \mathrm{~mm}$, EL: $2.2 \mathrm{~mm}$, EW: $1.9 \mathrm{~mm}$, PL: $0.8 \mathrm{~mm}$, PW: $1.7 \mathrm{~mm}$. Colour: Dorsal and ventral sides black; one very large band of orange coloration extending from the sides toward the elytral suture, not reaching elytral suture; tibiae light brown, tarsal claws light brown; 1st to 9 th AS light brown, 9th to 11th dark brown.

Body (Fig. 13). Head coarsely punctate with long, light brown setation. Palpi entirely yellowish-brown; setation on mentum denser. Eye very large, with brown microsetae. Ocellus on front present (Fig. 16). Antennae with short brown setae, with eleven antennomeres, 1 st and 2 nd AS round and wider than 3 rd to 6 th $\mathrm{AS}, 3 \mathrm{rd}$ to 6th AS width relatively consistent, length gradually increases from 3rd to 10th AS, 11th AS longest and semicircular (Fig. 17). Antennal fossa circular. Pronotum slightly more sparsely punctate compared to head, relatively consistent density of punctures, with relatively long yellowish-brown and dark brown setation, most of the setae in the middle of pronotum may be eroded. Scutellum triangular, anterior end convex, without setation. Elytra densely punctate compared to pronotum; surface long dark brown setae, long yellowish-brown setae present on the yellowish-brown marking, most of the setae in the middle of pronotum may be eroded (Fig. 13). Elytral epipleuron entirely light brown setation. Legs with light brown setation. Mesosternum coarsely punctate laterally, otherwise finely punctate, covered with light brown, short, recumbent setation (Fig. 14). Abdominal visible ventrites finely punctate, with long, recumbent, light brown setation (Fig. 15).

Male. Unknown.

DISTRIBUTION. Madagascar.

DIFFERENTIAL DIAGNOSIS. The new species similar to T. wolfgangi Háva et Herrmann, 2008 and T. horaki Háva, 2013 but differs from them by its characteristic elytral colour; from other species known from Madagascar it differs by the characters given in the key below.

ETYMOLOGY. The epithet is a patronym honouring David Sharp, who was a British coleopterist.

\section{Key to the known Madagascan species of Trogoderma}

1(4) Elytra uni-coloured.

2(3) Elytra uni-coloured, brown without fasciae or spots, covered with yellow pubescence; antennal club with five antennomeres

T. taomasinum Háva, 2009

3(2) Elytra uni-coloured, reddish brown to black with three white bands of setation; antennal club with five antennomeres ................................. T. tryznai Háva et Matsumoto, sp. n.

4(1) Elytra bi- or tri-coloured.

5(6) Body elongate; antennal club with seven antennomeres; elytra with three orange-red fasciae covered with yellow pubescence .............................. T. trifasciatum Háva, 2009

6(5) Body oval.

7(10) Antennal club with three antennomeres.

8(9) Terminal antennomere short and brown; lateral parts of pronotum orange; head finely punctured elytra brown with orange-red fasciae covered with white pubescence .......

T. fasciolata (Fairmaire, 1897)

9(8) Terminal antennomere long and black; lateral parts of pronotum dark brown or black; head coarsely punctured T. impressiceps (Pic, 1915) 
10(7) Antennal club with more than three antennomeres.

11(21) Antennal club with four antennomeres.

12(13) Elytra brown with small spots of white pubescence; BL: 3.1-3.5 mm

T. seminigrum Pic, 1915

13(12) Elytra with reddish bands or orange fasciae and spots.

14(00) Elytra black with four transverse, reddish bands and apical spot

15(18) Elytra with one orange fascia or one large orange spot.

16(17) Elytra with one orange fascia and apically isolated spot covered with yellow pubescence; BL: $1.6 \mathrm{~mm}$........................................................... T. horaki Háva, 2013

17(16) Elytra black with one large orange spot on apex and one transverse fascia of white pubescence in the middle

T. sambiranum Háva, 2009

18(15) Elytra with 3-4 transverse orange or reddish bands.

19(20) Elytra dark-brown with three transverse, orange bands (Fig. 22); aedeagus (Fig. 24) .. T. sahondrae Háva et Baňař, 2017

20(19) Elytra dark-brown to black with three transverse orange bands (Fig. 7); aedeagus (Fig. 12) T. zhantievi Háva et Matsumoto, sp. n.

21(11) Antennal club with 5-6 antennomeres.

22(23) Antennal club with six antennomeres; elytra black with small spots covered with white pubescence; BL: 1.7-2.2 $\mathrm{mm}$

T. madecassum (Pic, 1924)

23(22) Antennal club with five antennomeres.

22(27) Elytra with one orange transverse fascia.

25(26) Elytra with one orange transverse fascia, apical part covered with yellowish-white pubescence; BL: 2.2-2.5 mm

26(25) Elytra with one orange fasciae in anterior half

T. sharpi Háva et Matsumoto, sp. n.

27(22) Elytra entirely black or black with two very small spots.

28(29) Elytra black, covered with dark brown pubescence, with two very small spots formed by six to eight white setae; BL: $1.8 \mathrm{~mm}$

T. housei Háva, 2014

29(28) Elytra entirely black with three transverse fasciae of white setation

T. parasambiranum Háva, 2018

\section{NEW FAUNISTIC RECORDS}

\section{Phradonoma albonotatum (Pic, 1927)}

Fig 18

MATERIAL. 1 female deposited at BMNH: "NW MADAGASCAR 2015 AN-

KARAFANTSIKA N.P.; 25.i. circuit ,Source de vie ${ }^{\text {ee }}$ marking „, $1500 \mathrm{~m}^{\text {ee }}$ sifting for litter Winkler app. extr. local collector BMHN \{E\}2016-44 // NHMUK014381547”.

NOTES. It is a new locality data from Madagascar.

Trogoderma caneparii Háva, 2016

Fig 19

MATERIAL. 1 female deposited at BMNH: "AKF/04/2011 MADAGASCAR NW ANKARAFANTSIKA N.P.; 22.iv.2011 S16¹8’46.6"E4648’58.8”; 89 m sifting 
forest litter, Winkler app. extr. L.S. Rahanitriniania \& R. Raveloson lgt. // BMNH \{E\} 2015-39 // NHMUK014381548".

NOTES. It is a new locality data from Madagascar.

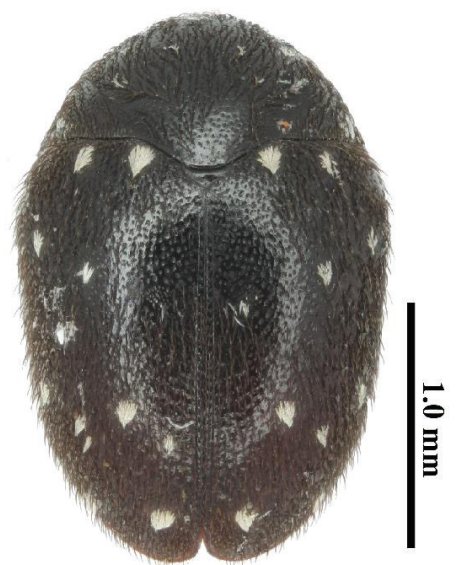

18

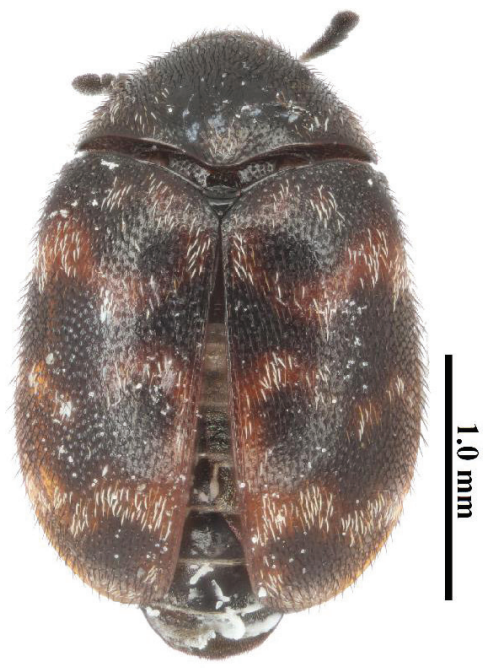

20
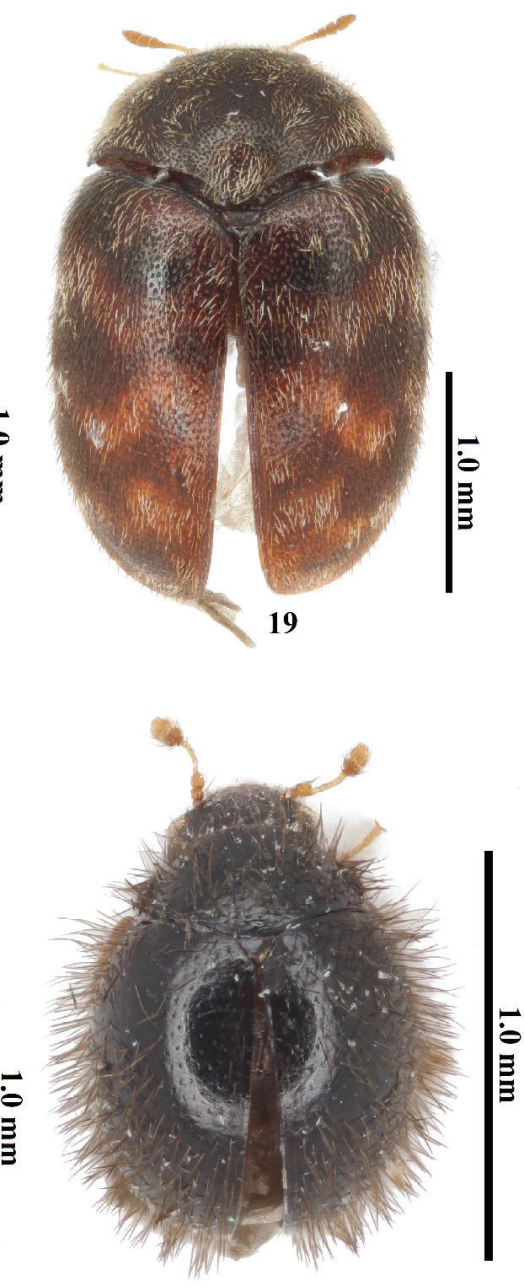

21

Figs. 18-21. Madagascan Dermestidae. 18 - Phradonoma albonotatum (Pic, 1927); 19 Trogoderma caneparii Háva, 2016; 20 - Trogoderma impressiceps (Pic, 1915); 21 - Trinoparvus laboriosus Háva, 2004. 
Trogoderma impressiceps (Pic, 1915)

Fig 20

MATERIAL. 1 male, deposited at BMNH: "MADAGASCAR 2011 AMBOHITANTELY Sp. Res 19.iv.; 1530 m, camp surr.; local collector lgt. // BMNH $\{\mathrm{E}\}$ 2015-39 // NHMUK014381549”.

NOTES. It is a new locality data from Madagascar.

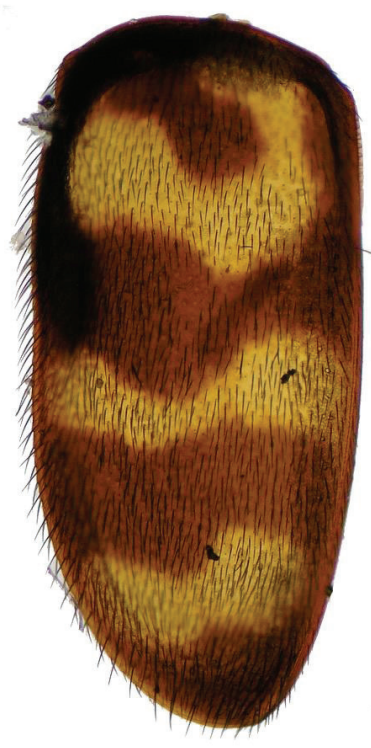

22

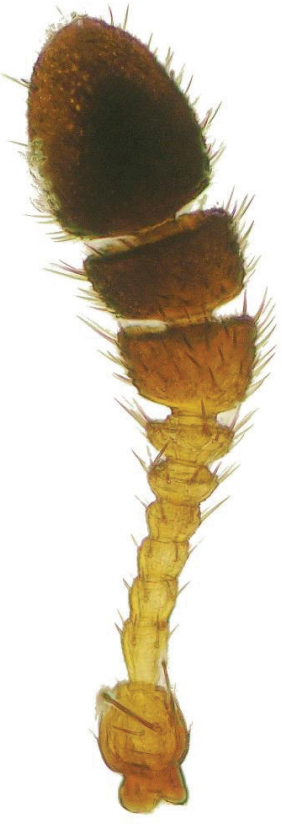

23

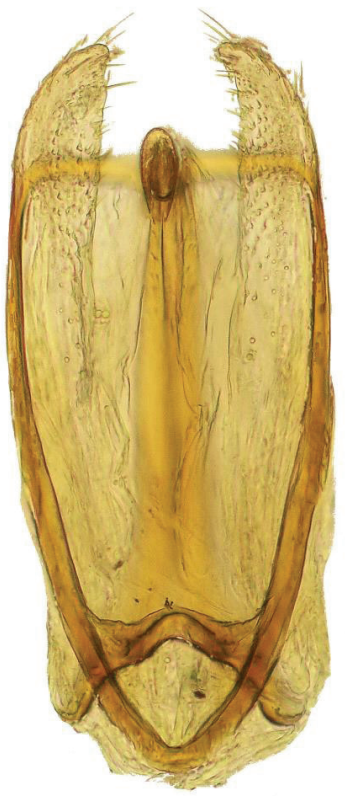

24

Figs. 22-24. Trogoderma sahondrae Háva et Baňař, 2017. 22 - elytron; 23 - antennae; 24 - genitalia ventral.

\section{Trinoparvus laboriosus Háva, 2004}

Fig. 21

MATERIAL. 2 males, 1 female, 5 ex. deposited at BMNH: “ABT/Nov.2011/10 MADAGASCAR AMBOHITANTELY Spec. Res.; 18.xi.2011; sifting forest litter under palm tree; Winkler app. extracion; 1600m; // BMNH \{E\} 2015-39 // NHMUK 014381550”, “ABT/Nov.2011/17 MADAGASCAR AMBOHITANTELY Spec. Res.; 
1593m S18 11'48.6"E47¹7’05.7"; 21.xi 2011; sifting litter, wet material by stream; Winkler app. extr. L.S. Raha-nitriniaina lgt. // BMNH $\{\mathrm{E}\}$ 2015-39 // NHMUK014381551”, “ABT/Nov.2011/07 MADAGASCAR AMBOHITANTELY

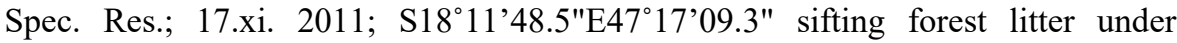
Pandanus Winkler app. extraction; 1595m dry material // BMNH\{E\} 2015-39 // NHMUK014381552”, “ABT/Nov.2011/01 MADAGASCAR AMBOHITANTELY Spec. Res.; 16.xi. 2011; S18 11'52.7"E47¹7'0.4" 1603m; sifting litter under Pandanus Winkler app. extr. L.S. Raha-nitriniaina lgt. // BMNH\{E\} 2015-39 // NHMUK014381553”, “ABT/Nov.2011/16 MADAGASCAR AMBOHITANTELY Spec. Res.; 1620m S18 11'42.6"E47'17'10.8"; 21.xi. 2011; sifting litter under Pandanus; Winkler app. extr.; L.S. Rahanitri-niaina lgt. // BMNH\{E\} 2015-39 // NHMUK014381554”, “ABT/Nov.2011/16 MADAGASCAR AMBOHITANTELY Spec. Res.; 1620m S18 11'42.6"E47'17'10.8"; 21.xi. 2011; sifting litter under Pandanus; Winkler app. extr.; L.S. Rahanitri-niaina lgt. // BMNH\{E\} 2015-39 // NHMUK014381555”, “ABT/Nov.2011/18 MADAGASCAR AMBOHITANTELY Spec. Res.; 1614 S18 11'48.7"E47'17'11.3"; 22.xi 2011; sifting litter under palm trees Winkler app. extr. L.S. Raha-nitriniaina lgt. // BMNH\{E\} 2015-39 // NHMUK 014381556" and "ABT/Nov.2011/18 MADAGASCAR AMBOHITANTELY Spec. Res.; 1614 S18 11'48.7"E47²1'11.3"; 22.xi 2011; sifting litter under palm trees Winkler app. extr. L.S. Raha-nitriniaina lgt. // BMNH\{E\} 2015-39 // NHMUK014381557".

NOTES. It is a new locality data from Madagascar.

\section{ACKNOWLEDGEMENTS}

The paper was supported by the Ministry of Agriculture of the Czech Republic, institutional support MZE-RO0118. We would like to express thanks to Max Barclay (BMNH) and anonymous reviewers for comments on the manuscript.

\section{REFERENCES}

Háva, J. 2009. Review of the genus Trogoderma from Madagascar (Coleoptera: Dermestidae: Megatominae). Baltic Journal of Coleopterology, 9: 111-117.

Háva, J. 2013. A new Trogoderma species from Madagascar (Coleoptera: Dermestidae: Megatominae). Arquivos Entomoloxicos, 9: 3-5.

Háva, J. 2014. A contribution to the genus Trogoderma from Madagascar (Coleoptera: Dermestidae: Megatominae). Folia Heyrovskyana, Series A, 21: 41-44.

Háva, J. 2015. World Catalogue of Insects. Volume 13. Dermestidae (Coleoptera). Brill, Leiden/Boston. xxvi $+419 \mathrm{pp}$.

Háva, J. 2018. Two new Trogoderma species from Madagascar (Coleoptera: Dermestidae: Megatominae). Baltic Journal of Coleopterology, 18(1): 121-127.

Háva, J. 2020. Dermestidae World (Coleoptera). World Wide Web electronic publication, version 2018, update January 2020. Available from: http://www.dermestidae.wz.cz 
Háva, J. \& Baňař, P. 2017. A new Trogoderma species from Central Madagascar (Coleoptera: Dermestidae: Megatominae). Zootaxa, 4299(2): 279-284. DOI: https://doi.org/ 10.11646/zootaxa.4299.2.8

Háva, J. \& Herrmann, A. 2008. Trogoderma wolfgangi sp. n. (Coleoptera: Dermestidae: Megatomini) from Madagascar. Calodema Supplementary Paper, 88: 1-4. 